\title{
New insights into plastid nucleoid structure and functionality
}

\author{
Karin Krupinska $\cdot$ Joanna Melonek $\cdot$ Kirsten Krause
}

Received: 12 September 2012/ Accepted: 9 November 2012/Published online: 5 December 2012

(C) Springer-Verlag Berlin Heidelberg 2012

\begin{abstract}
Investigations over many decades have revealed that nucleoids of higher plant plastids are highly dynamic with regard to their number, their structural organization and protein composition. Membrane attachment and environmental cues seem to determine the activity and functionality of the nucleoids and point to a highly regulated structure-function relationship. The heterogeneous composition and the many functions that are seemingly associated with the plastid nucleoids could be related to the high number of chromosomes per plastid. Recent proteomic studies have brought novel nucleoidassociated proteins into the spotlight and indicated that plastid nucleoids are an evolutionary hybrid possessing prokaryotic nucleoid features and eukaryotic (nuclear) chromatin components, several of which are dually targeted to the nucleus and chloroplasts. Future studies need to unravel if and how plastid-nucleus communication depends on nucleoid structure and plastid gene expression.
\end{abstract}

Keywords Plastid nucleoid-associated proteins . Plastid nucleoid structure - Plastid gene expression . Transcriptionally active chromosome

Abbreviations
$\begin{array}{ll}\text { ptNAP } & \text { Plastid nucleoid-associated protein } \\ \text { NEP } & \text { Nuclear-encoded plastid RNA polymerase }\end{array}$

K. Krupinska $(\bowtie) \cdot$ J. Melonek

Institute of Botany, University of Kiel,

Olshausenstraße 40, 24098 Kiel, Germany

e-mail: kkrupinska@bot.uni-kiel.de

\section{K. Krause}

Department for Arctic and Marine Biology,

University of Tromsø, Dramsvegen 201,

9037 Troms $\varnothing$, Norway
PEP Plastid-encoded plastid RNA polymerase

ptDNA Plastid DNA

TAC Transcriptionally active chromosome

\section{Introduction}

Plastid DNA is assembled in complex structures of high molecular weight that are attached to intraplastidial membranes and contain proteins as well as RNA. These structures, termed plastid nucleoids or plastid nuclei (Sakai et al. 2004), are associated with numerous enzymatic activities such as DNA repair, DNA replication, recombination, transcription and post-transcriptional control of gene expression. Microscopic studies showed that the localization and composition of the complexes are dynamic and undergo age-dependent changes that could be coupled to changes in the overall activity and specificity of RNA polymerases and components of other regulatory levels of plastid gene expression.

For a long time, knowledge about the protein components of the plastid nucleoid was limited to information from biochemical studies, which was summarized in excellent reviews by Sato and co-workers (Sato et al. 2003) as well as by Sakai and co-workers (2004). The improvement of bioinformatic targeting predictions, GFP-based analysis of subcellular protein localization and last but not least the increasing sensitivity of proteome analyses have led to a recent sharp increase in our knowledge of the composition of the plastid nucleoids. Among the newly identified proteins are DNA binding proteins with eukaryotic motifs for which a dual targeting activity to the plastids and the nucleus has either been demonstrated or is postulated. The current review will concentrate mainly on 
these recent advances and will refer to older knowledge only when necessary for the integrated picture of the whole nucleoid. We therefore apologize to those whose work could not be cited due to space limitations.

\section{Dynamics in the organization of the multicopy chloroplast genome in higher plants}

As indicated by the formation of nucleoids, plastids have kept many of the structural and organizational features of their prokaryotic ancestors. On the other hand, they have also evolved several unique features. For example, the conformation of the plastid DNA exhibits a much greater structural complexity and variability than that of their bacterial counterparts. Investigations have revealed that in addition to the circular forms also linear as well as branched monomers and multimers with defined ends can occur (Bendich 2004; Bock 2007). The fundamental difference between genome organization in plastids versus that in bacteria is that the plastids are multi-nucleated as opposed to the single-nucleated organization of their prokaryotic counterparts (Sakai et al. 2004). In higher plants, the plastid genome occurs in high copy numbers which differ in various organs and cell types (Boffey et al. 1979; Mullet 1993). In mesophyll cells of green leaves, numbers in the range from 2,000 to 50,000 genomes per cell were estimated (Kuroiwa et al. 1982; Bendich 1987; Coleman and Nerozzi 1999). On average, 10-20 copies of the plastid genome are organized into a variable number of structures that originally were named plastid nucleoids due to their resemblance to their bacterial counterparts (Kuroiwa 1991). Plastid nucleoids exhibit tremendous differences with respect to number, shape and distribution that parallel the developmental changes in structure and function of plastids (Sato et al. 2003). Differences in nucleoid number and morphology seem to occur also in different sectors of variegated leaves (Sakamoto et al. 2009) and during plastid division.

In yeast mitochondria, there is evidence for a functional variance among the multiple nucleoids within one mitochondrion. An actively replicating type can be distinguished from a non-replicating type by its association with a proteinaceous structure spanning the inner and the outer membrane (Meeusen and Nunnari 2003). Given the significant morphological differences among plastid nucleoids, structural and functional variance among the multiple nucleoids of a single chloroplast is also likely. In fact, sizes and positions of different nucleoid sub-populations could very well reflect the different requirements for enzymatic activities within the plastid nucleoids during plastid biogenesis. First support for this comes from co-localization studies of different plastid nucleoid-associated proteins (ptNAPs) (Melonek et al. 2010).

\section{Sub-nucleoid domains}

A functional diversification in different zones was reported for nucleoids of mitochondria (Shutt et al. 2010) and bacteria (Dillon and Dorman 2010) as well as for the chromatin in the nucleus (Shaw and Brown 2004; Matera et al. 2009). The benefit of these sub-compartmental structures is concentration of DNA-binding proteins and DNA-regions to certain areas, which might enhance the rates of biochemical reactions associated with gene expression and might confer an evolutionary advantage over a random chromatin architecture (Matera et al. 2009).

Evidence for discernible sub-domains with different specific functions has also been found within plastid nucleoids. Initial reports from electron microscopic studies, which showed that the de-proteinized spinach plastid chromosome is organized in a folded form around a central body composed of proteins which are not extractable by usual procedures (Herrmann et al. 1974; Yoshida et al. 1975), were soon followed by biochemical data that confirmed the observation that proteins are either firmly bound to DNA in a central region or are more loosely bound to the peripheral DNA fibrils. These observations led to the proposal of a layered structure of plastid nucleoids (Briat et al. 1982; Hansmann et al. 1985; reviewed by Sakai et al. 2004) (see Fig. 1). An estimated $30-50 \%$ of the ptDNA is incorporated in the central body. Surprisingly, ultrastructural studies revealed that the DNA loops protruding from the core of chloroplast nucleoids are lacking in nucleoids from chromoplasts of Narcissus pseudonarcissus (Hansmann et al. 1985). Even though this indicates that the layered structure is not static but rather under developmental control, it is unclear what determines the relative proportions and degrees of compaction in the nucleoid layers and whether the observed changes have functional consequences.

Some authors have compared the dense nucleoid core with eukaryotic heterochromatin and the more dispersed peripheral regions with eukaryotic euchromatin where transcription is active (Sato and Ohta 2001; Sato et al. 2003). However, this contrasts with the observation that even highly condensed plastid DNA can be actively transcribed (Kuroiwa et al. 1990). The latter, in fact, corresponds well with the current model of mitochondrial nucleoid architecture in which replication and transcription were suggested to occur in the central core whereas translation and complex assembly occur in peripheral regions (Bogenhagen et al. 2008). Sakai and co-workers (Sakai et al. 2004) in fact suggested that the central body is involved in membrane binding and that this is a prerequisite for active transcription. On the other hand, at least one type of plastid RNA polymerase, namely the NEP encoded by the RPOTmp gene seems to be sensitive to 


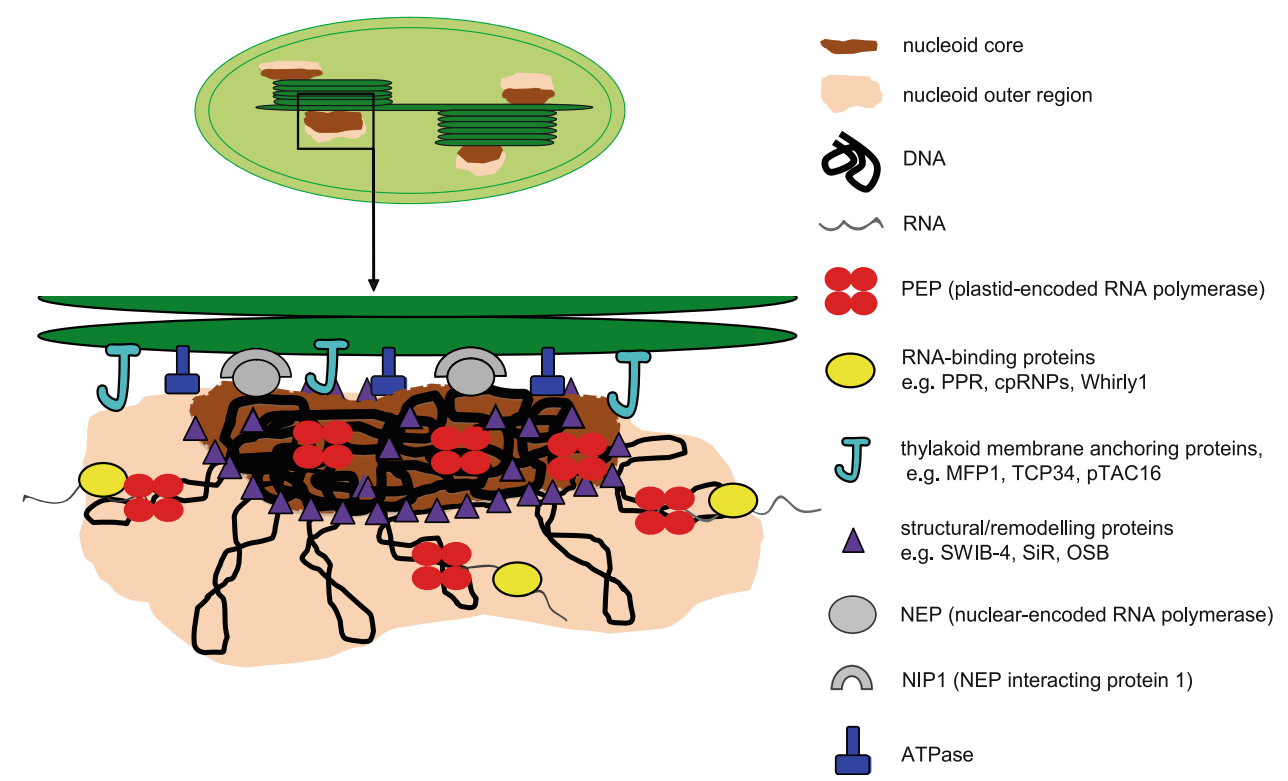

Fig. 1 Model for the layered structure of plastid nucleoids. Plastid nucleoids consist of a dense layer, or nucleoid core, where proteinDNA interactions are insensitive to salt or detergent treatments (see text) and where transcriptional activity is particularly high (Sakai et al. 2004). Several membrane anchor proteins in this layer can mediate the attachment of the DNA to plastidial membranes. The nucleoid core is surrounded by a second layer where DNA-protein interactions and possibly DNA compaction are less tight. Switching

membrane binding and was proposed to be switched off when it is brought into close proximity of the thylakoid membranes. This sensitivity might be conferred by a thylakoid membrane-embedded RING protein, NIP1 (NEP interacting protein 1), that showed specific interaction with RPOTmp (Azevedo et al. 2008), reflecting the complex interplay between structure, distribution and activity.

Considering that the two plastid nucleoid layers or subdomains could have different functionality, they would also be expected to have different sets of proteins. Whether they, in addition, attract different chromosomal regions, has not been answered conclusively but there is some evidence for this. For example, the analysis of transcripts synthesized by highly purified transcriptionally active chromosomes (TAC) that resemble the central body, revealed that ribosomal RNA transcripts were enriched (Krause and Krupinska 2000). This might indicate a spatial organization of different transcription foci similar to what has been found in bacteria (Cabrera and Jin 2003, 2006).

\section{Analysis of the protein composition of plastid nucleoids}

Plastid nucleoids can be prepared by different methods. Most preparations were done by either sucrose density gradient centrifugation (Nemoto et al. 1988; Cannon et al. 1997) or by gel filtration of extracts prepared from plastid between the "core DNA" conformation and the "surrounding DNA" conformation could be mediated by chromatin remodeling proteins like SWIB-4 that are depicted here exemplarily at the interface between the two layers. Other membrane-associated proteins like the NEP interacting protein NIP can selectively control the activity of the NEP polymerase by preventing its association with plastid DNA (Azevedo et al. 2008)

membranes treated with detergents (Hallick et al. 1976; Krause and Krupinska 2000). The DNA containing fraction prepared by gel filtration was called TAC, because it has been used initially to determine the activity and composition of the transcriptional apparatus (see reviews of Gruissem and Tonkyn 1993; Igloi and Kössel 1992; Sakai et al. 2004, and references therein). The TAC fraction is prepared from plastid membranes by release of the nucleoids with detergents and by subsequent purification involving sepharose gel filtration and other steps (Krause and Krupinska 2000; Pfalz et al. 2006). Recent proteomic analyses of these (Pfalz et al. 2006; Melonek et al. 2012) and other nucleoid-enriched fractions (Phinney and Thelen 2005; Majeran et al. 2012) have revealed that several of the newly identified DNA binding proteins were not inherited from the prokaryotic ancestors. Plastid proteins homologous to the abundant prokaryotic HU protein, on the other hand, were not detected in higher plants which stands in contrast to their identification in some algal plastids (Karcher et al. 2009), in the apicoplasts of apicomplexans (Sato et al. 2003) as well as in some dinoflagellates (Chan et al. 2006).

In analogy to the nomenclature proposed for bacterial nucleoid-associated proteins (NAPs) (Dillon and Dorman 2010), proteins of the plastid nucleoids are here designated plastid nucleoid-associated proteins (ptNAPs). NAPs contribute to both nucleoid structure and gene regulation and 
an according classification has been discussed (Dillon and Dorman 2010). In this review we follow a simplified classification into enzymatic ptNAPs (including transcription, post-transcriptional levels of gene expression, DNA replication and repair) and architectural ptNAPs (including membrane anchoring and DNA compaction). It should be kept in mind, however, that the architecture can have an influence on transcriptional activity and on the formation of transcriptional foci in bacteria (Berger et al. 2010) and that the same is likely the case in plastids.

\section{Enzymatic ptNAPs}

\section{Transcription}

A number of functional activities have been associated with the nucleoids of plastids. These include the transcription of plastid genes. Accordingly, core subunits of the plastid-encoded RNA polymerase, PEP, have been identified in most of the proteomic studies of plastid nucleoid fractions of dicots (i.e. Arabidopsis, mustard, spinach, pea) (Phinney and Thelen 2005; Pfalz et al. 2006; Melonek et al. 2012) as well as monocots (i.e., maize) (Majeran et al. 2012). A preparation, where only the core PEP and very tightly associated subunits were preserved, contained an additional ten proteins that were termed PEP-associated proteins (for PAPs) (Steiner et al. 2011). These PAPs seem to be closely associated accessory subunits of the PEP core. In a recent detailed study, one of them, the PAP1/pTAC3 protein, was confirmed to be an essential component of the chloroplast PEP complex during transcription initiation, elongation and termination (Yagi et al. 2012).

Besides PEP, a nuclear-encoded plastid RNA polymerase, NEP, has been postulated to be involved in plastid gene transcription (for a recent review see Liere et al. 2011). So far, this NEP has neither been identified in the TAC fraction nor in the soluble protein fraction (Pfannschmidt and Link 1994; Krause and Krupinska 2000) that has recently been subjected to proteomic analysis (Schröter et al. 2010) nor in any of the nucleoid or TAC proteomes. It is, therefore, likely that its amount is below the detection limit even of the currently available analytical methods.

Interestingly, only one sigma factor (Sigma 2) could be identified in the nucleoid preparations performed with maize seedlings (Majeran et al. 2012) while no sigma factors were detected in preparations of the soluble RNApolymerase fraction (Suzuki et al. 2004; Schröter et al. 2010) including fractions enriched in PEP (Steiner et al. 2011). The reason for this failure might be that the proteins escaped detection due to very low abundance. However, it is equally possible that the transient interactions of these factors with the DNA are too weak to grant a co-purification. The same could be true for the putatively dually targeted transcription factors with eukaryotic binding motifs that were identified in bioinformatic screens (Wagner and Pfannschmidt 2006; Schwacke et al. 2007) as well as for the Sigma factor binding proteins (SIB) 1 and 2 (Morikawa et al. 2002; Lai et al. 2011). For the SIBs, experimental data were recently provided that they are, in fact, dually targeted to the nucleus and the plastids (Lai et al. 2011).

Post-transcriptional levels of gene expression

In the TAC fraction of spinach (Melonek et al. 2012) two members of the cpRNP family (CP29B, CP31A) have been found. In the TAC proteome analysis described by Pfalz et al. (2006) a PPR protein with a molecular weight of $97 \mathrm{kDa}$ (pTAC2) was identified. Interestingly, Phinney and Thelen (2005) identified a pea protein of similar size in their nucleoid analysis which matched the monoisotopic masses of the same PPR protein, corroborating its presence in chloroplast nucleoids. In a recent analysis of spinach TAC, two further PPR proteins of 98 and $67 \mathrm{kDa}$ were identified (Melonek et al. 2012). Since cpRNPs and PPRs are both involved in organellar RNA processing and translation (Schmitz-Linneweber and Small 2008; Ruwe et al. 2011), this indicates that post-transcriptional levels of gene expression such as RNA stability and turnover are at least in part closely connected to the nucleoids. This is in line with the notion that ribosomes seem to be quite closely associated with the nucleoids of plastids (Phinney and Thelen 2005; Pfalz et al. 2006). This close association of ribosomal subunits with the DNA-protein complexes is, in fact, a common trait between plastid and mitochondrial nucleoids (see Kucej and Butow 2007; Nosek et al. 2006, and references cited within), and also explains the occurrence of proteins involved in translation in all plastid nucleoid fractions containing subunits of PEP (Phinney and Thelen 2005; Pfalz et al. 2006; Majeran et al. 2012; Melonek et al. 2012) (Table 1). Their systematic occurrence in diverse preparations and organisms suggests that post-transcriptional processing steps and translational activity are probably closely associated with the nucleoids (Majeran et al. 2012). This is also in accordance with reports from bacterial nucleoids (Gowrishankar and Harinarayanan 2004).

\section{DNA methylation}

Methylation of plastid DNA and its potential effects on gene expression has in the past been discussed controversially. While early reports could convincingly demonstrate that DNA methylation is crucial for the regulation of transcription during differentiation of amyloplasts in 
Table 1 Examples for ptNAPs with a metabolic function in plastids
${ }^{\text {a }}$ Functions which have been experimentally demonstrated

\begin{tabular}{|c|c|c|c|}
\hline NAP & $\begin{array}{l}\text { Arabidopsis } \\
\text { homolog }\end{array}$ & $\begin{array}{l}\text { Metabolic } \\
\text { function }\end{array}$ & Evidence for nucleoid association \\
\hline $\begin{array}{l}\text { NmrA-like/ } \\
\text { pTAC16 }\end{array}$ & At3g46780 & $\begin{array}{l}\text { NADP-dependent reductase/ } \\
\text { dehydrogenase }\end{array}$ & $\begin{array}{l}\text { Proteomic (Phinney and Thelen 2005; } \\
\text { Pfalz et al. 2006; Majeran et al. 2012) }\end{array}$ \\
\hline FSD2, FSD3 & $\begin{array}{l}\text { At5g51100 } \\
\text { At5g23310 }\end{array}$ & $\begin{array}{l}\text { Iron superoxide dismutase } \\
\quad(\text { Myouga et al. 2008) })^{\mathrm{a}}\end{array}$ & $\begin{array}{l}\text { Proteomic (Pfalz et al. 2006; Myouga } \\
\text { et al. 2008) }\end{array}$ \\
\hline TRX Z & At3g06730 & $\begin{array}{l}\text { Thioredoxin (Arsova et al. } \\
2010)^{\mathrm{a}}\end{array}$ & $\begin{array}{l}\text { Proteomic (Pfalz et al. 2006; Majeran } \\
\text { et al. 2012) }\end{array}$ \\
\hline $\mathrm{SiR}$ & & $\begin{array}{l}\text { Ferredoxin:sulfite reductase } \\
\text { precursor (Kang et al. } \\
\text { 2010; Sekine et al. 2007) }\end{array}$ & $\begin{array}{l}\text { Proteomic, Western blot, } \\
\text { immunofluorescence, gene silencing } \\
\text { (Phinney and Thelen 2005; Kang } \\
\text { et al. 2010; Sekine et al. 2007) }\end{array}$ \\
\hline MurE & At1g63680 & Mur ligase & $\begin{array}{l}\text { Proteomic (Pfalz et al. 2006; Majeran } \\
\text { et al. 2012) }\end{array}$ \\
\hline Rca & At2g39730 & Rubisco activase & $\begin{array}{l}\text { Proteomic (Phinney and Thelen 2005; } \\
\text { Melonek et al. 2012) }\end{array}$ \\
\hline ClpC1/C2, ClpD & $\begin{array}{l}\text { At5g50920 } \\
\text { At3g48870 } \\
\text { At5g51070 }\end{array}$ & Protease; chaperonin & $\begin{array}{l}\text { Proteomic (Phinney and Thelen 2005; } \\
\text { Majeran et al. 2012) }\end{array}$ \\
\hline ATPase subunits & $\begin{array}{l}\text { Chloroplast } \\
\text { encoded }\end{array}$ & ATP generation & $\begin{array}{l}\text { Proteomic (Phinney and Thelen 2005; } \\
\text { Pfalz et al. 2006; Melonek et al. } \\
\text { 2012) }\end{array}$ \\
\hline $\begin{array}{l}\text { Aminotransferase- } \\
\text { like protein } 1\end{array}$ & At3g05190 & $\begin{array}{l}\text { Branched-chain amino acid } \\
\text { biosynthesis }\end{array}$ & Proteomic (Melonek et al. 2012) \\
\hline CND41 & At5g10760 & $\begin{array}{l}\text { DNA-binding aspartate } \\
\text { protease (Murakami et al. } \\
2000)^{\mathrm{a}}\end{array}$ & Immunoblot (Nakano et al. 1997) \\
\hline
\end{tabular}

RNA polymerase, Pol I or POP (reviewed by Moriyama et al. 2010). Along with DNA gyrases, it belongs to the enzymes whose presence in TAC proteomes was shown repeatedly (Phinney and Thelen 2005; Pfalz et al. 2006; Ono et al. 2007).

In the proteomic study of thylakoid membranes isolated from pea chloroplasts, a homolog of the bacterial RecA protein (RecA1) could be identified (Phinney and Thelen 2005). Members of the Rec family are associated in general with recombinational activities. One protein with a RecF/ RecN/SMC domain has also been identified in the spinach TAC proteome (Melonek et al. 2012). In rice, two RecQlike helicases, OsRecQ1 and OsRecQsim, were found to be targeted to the plastids and were discussed as components of a plastid-specific DNA-repair system (Saotome et al. 2006). It has also been reported, that the two plastidlocated Whirly proteins AtWhy1 and AtWhy3 that have been identified in TAC proteomes (Pfalz et al. 2006) function as anti-recombination proteins contributing to safeguard plastid genome integrity (Marechal et al. 2009). Whirly proteins can bind to single stranded DNA and RNA (Desveaux et al. 2000; Prikryl et al. 2008) and seem to assume a number of important functions in nucleoid metabolism. Like the Whirly group of proteins, the organellar single stranded DNA binding proteins (OSBs) belong to a small family of proteins involved in ptDNA
The polymerase that is responsible for the replication of plastid chromosome has originated from the mitochondrial 
stability and recombination surveillance (Marechal and Brisson 2010). OSB2 alias pTAC9 was identified in the Arabidopsis TAC proteome (Pfalz et al. 2006) while OSB1 was found to be associated with nucleoids in maize (Majeran et al. 2012). Other proteins proposed to be involved in plastid DNA repair are Arp1, Nth2 and MutS. MutS is dually localized to plastids and mitochondria and has been postulated to be involved in DNA recombination and to influence genome stability and plastid development (Xu et al. 2011).

\section{Architectural ptNAPs}

\section{Membrane anchoring}

While bacterial nucleoids are associated with the cytoskeleton (Travers and Muskhelishvili 2005), organellar nucleoids are attached to intraplastidial membranes that were proposed to serve as a platform for DNA synthesis and transcription (Sakai et al. 2004). Consequently, many of the architectural nucleoid proteins that have so far been identified in plastids are involved in anchoring the nucleoids to either envelope membranes (PEND, PD1, PD3) or thylakoid membranes (MFP1, TCP34, pTAC16).

\section{PEND}

The plastid envelope DNA binding protein (PEND) is a $70 \mathrm{kDa}$ membrane-spanning protein with a basic region plus leucine zipper (bZIP) domain that forms dimers in vivo which seem to tether the nucleoids to the plastid inner envelope (Sato et al. 1993, 1998). The PEND protein was initially discovered in developing pea chloroplasts (Sato et al. 1993). Homologs were later detected in other angiosperms, e.g., in Brassica napus (Waldmüller et al. 1996) while functional homologs in algae and in nonflowering plants are still not known (Terasawa and Sato 2005a). The cbZIP domain of PEND was shown to bind selectively to AT-rich regions of plastidic DNA containing the canonical sequence TAAGAAGT (Sato and Ohta 2001). Interestingly, both the PEND protein from Brassica napus and its rapeseed homolog, GSBF1, were found to repress the expression of the nuclear-encoded $r b c S$ gene (Waldmüller et al. 1996; Wycliffe et al. 2005). That PEND indeed fulfills a direct role in the nucleus was supported by the recent observation that a PEND:GFP fusion protein is targeted to the nucleus when the $\mathrm{N}$-terminal presequence is deleted (Terasawa and Sato 2009). It has been proposed that the PEND protein might be first targeted to plastids where the $\mathrm{N}$-terminal presequence is cleaved and that it might be relocated to the nucleus when the chloroplast envelope is degraded by accident or by some kind of physiological process (Terasawa and Sato 2009). Interestingly, to date PEND has been only identified by proteome analysis of a Triton-insoluble fraction of nucleoids (Phinney and Thelen 2005). This could indicate that the integration of PEND inside the envelope membrane is so stable that it was not extracted by any detergent used by the other methods enriching nucleoids.

\section{PD1 and PD3}

PD1 and PD3 (plastid DNA binding 1 and 3, respectively) were detected during research on PEND (Sato et al. 1995) and are both characterized by the possession of AT-hook motifs. These motifs were originally associated with the high mobility group I (HMG-I) of nuclear proteins and seem to interact with the minor groove of AT-rich regions of nuclear DNA (Grasser 1995). In addition to the two or five AT-hooks of PD1 and PD3, respectively, PD3 possesses eight $\mathrm{CxxC}$ motifs, which are presumed to be metal binding sites of the protein (Sato et al. 1995). PD3 also has a Jumonji $\mathrm{C}$ (jmjC) domain at the $\mathrm{C}$-terminus which was proposed to be involved in chromatin remodeling (Kodama 2007). Structural data suggest that these plastid DNA binding proteins have evolved from nuclear transcription factors containing AT-hook motifs (Kodama 2007). The localization of the PD1 and PD3 proteins to the plastid nucleoids was shown by immunological analysis with specific antibodies. In contrast to PEND which was shown to be distributed between membrane and stroma fractions, PD1 and PD3 were exclusively found in membrane fractions including the attached nucleoids (Sato et al. 1995). Similarly as PEND, neither of the two proteins was detected in the proteomes of recent nucleoid or TAC preparations from chloroplasts.

\section{MFP1, TCP34 and pTAC16}

The MAR binding filament-like protein 1 (MFP1) mediates the attachment of nucleoids to thylakoid membranes. MFP1 was first described in tomato as a nuclear DNA binding protein that connects chromatin with the nuclear envelope via matrix attachment regions (MAR) (Meier et al. 1996). MFP1, as an anchor protein, has an additional N-terminal hydrophobic membrane-spanning domain (Meier et al. 1996). Its targeting to the thylakoid membranes of chloroplasts was detected some years later and MFP1 is now known to be involved in anchoring the nucleoids to the thylakoid membranes with the C-terminal DNA-binding domain orientated towards the stroma (Jeong et al. 2003) (see model in Fig. 1). Another protein possibly involved in anchoring of plastid nucleoids to thylakoid membranes is the tetratricopeptide-containing chloroplast protein of $34 \mathrm{kDa}$ (TCP34), which was shown to stably 
associate with thylakoid membranes (Weber et al. 2006). Immunological analysis revealed that the protein is a TAC component (Weber et al. 2006; Melonek et al. 2010). The recombinant TCP34 protein showed specific binding to chloroplast DNA isolated from spinach (Weber et al. 2006). Very recently, it was postulated that next to MFP1 and TCP34 also the pTAC16 protein could anchor DNA to the thylakoid membranes (Ingelsson and Vener 2012; Majeran et al. 2012).

\section{Nucleoid/DNA compaction}

\section{$\operatorname{SiR}$}

Sulfite reductase $(\mathrm{SiR})$ is one of the most abundant proteins of nucleoids with a molecular weight of $70 \mathrm{kDa}$. It was shown to repress the transcriptional activity in isolated nucleoids by compacting their DNA (Sekine et al. 2002). In contrast to the PEND protein its binding to DNA is apparently sequence-independent. Nevertheless, it was shown in a recent study that the depletion of $\mathrm{SiR}$ leads to a significant downregulation of the expression of some chloroplast genes whereas others were unaffected or even upregulated (Kang et al. 2010). This provides important evidence that DNA compaction and gene expression are linked and that the level of compaction is not homogenous in the nucleoids. The $68 \mathrm{kDa}$ protein DCP68 which an earlier report linked to a suppression of ptDNA replication (Cannon et al. 1998) was found to correspond to SiR. SiR, which initially has been identified as a sulfite reductase is therefore a bifunctional (Sato et al. 2001) or even multifunctional protein. It has been shown that binding to DNA does not influence the sulfite reductase activity (Sekine et al. 2007) but, whether, vice versa, the enzymatic activity modulates the DNA compacting activity is not known. Such interplay would be of particular interest, as it would potentially link gene expression to chloroplast metabolism. So far, SiR has been detected in the proteome of a Tritoninsoluble plastid fraction that is enriched in NAPs but is devoid of membranes (Phinney and Thelen 2005).

\section{CND41}

The chloroplast nucleoid DNA binding protein of $41 \mathrm{kDa}$ (CND41) is another protein that binds non-specifically to plastid DNA via a helix-turn-helix motif and a putative zinc finger motif. It was identified initially in nucleoids isolated from cultured tobacco cells (Nakano et al. 1993). CND41 has been regarded as a negative regulator of transcription because its abundance in various tissues negatively correlates with the levels of certain plastid mRNAs (Nakano et al. 1997). Its sequence is similar to those of aspartic proteases and it exhibits strong proteolytic activity at an acidic $\mathrm{pH}$ (Murakami et al. 2000). It could be shown that CND41 is involved in Rubisco degradation and in the translocation of nitrogen during senescence (Kato et al. 2004). In senescent leaves of barley its expression was shown to be down-regulated (Parrott et al. 2007). This suggests that the activity of CND41 is associated with the maintenance of chloroplast function and not to dismantling of chloroplasts.

\section{$Y L M G 1$}

A protein involved in nucleoid distribution, AtYLMG1-1 was discovered recently by Kabeya and co-workers (Kabeya et al. 2010). While plastids of wild-type Arabidopsis thaliana contain a filamentous network of multiple nucleoids during chloroplast division (Terasawa and Sato 2005b), overexpression or knockdown of AtYLMG1-1 caused the formation of an irregular network of chloroplast nucleoids or aggregation of the nucleoids as larger structures, respectively (Kabeya et al. 2010). Immunofluorescence studies revealed that AtYLMG1-1 forms a punctuate pattern in close proximity to thylakoid membranes and possibly co-localizes with nucleoids (Kabeya et al. 2010).

\section{SWIB-4}

Among the 46 proteins identified in the highly enriched TAC-II fraction from spinach chloroplasts a small molecular weight protein containing a SWIB (for SWI/SNF complex b) domain was identified (Melonek et al. 2012). The SWIB domain represents a conserved region found in human BAF60b proteins (Bennett-Lovsey et al. 2002) that are known components of SWI/SNF (for switching defective/sucrose non fermenting) chromatin remodeling complexes originally identified in yeast (Burns and Peterson 1997). Sequences for 20 SWIB domain-containing proteins are present in the genome of Arabidopsis thaliana, six of which are predicted to localize to mitochondria and/or chloroplasts and the nucleus. By fusion with GFP, the chloroplast localization for four of them (SWIB-2, SWIB3, SWIB-4 and SWIB-6) could be confirmed (Melonek et al. 2012). Interestingly, out of the four plastidic SWIBs, only SWIB-4 has a histone H1 like motif (KKPAAKPKAK AKPKPKAKSDSPAK). A SWIB-4:GFP fusion protein was located in plastids and the nucleus (Melonek et al. 2012), placing SWIB-4 alongside several other dually targeted nucleoid proteins like PEND, MFP1, Whirly1 and others (Krause and Krupinska 2009). Overexpression of the SWIB-4 protein in Escherichia coli led to complete arrest of bacterial cell growth caused by compaction of the nucleoid (Melonek et al. 2012). In a complementation study of an E. coli mutant lacking HNS, an abundant NAP 
in bacteria, the compacting function of SWIB-4 could be confirmed (Melonek et al. 2012).

Proteins replacing $\mathrm{HU}$ and histones

The SWIB domain proteins identified in chloroplasts were shown to have low molecular masses, high isoelectric point and high lysine content (Melonek et al. 2012). They hence belong to those DNA-binding proteins biochemically detected in thylakoids and nucleoid fractions (Briat et al. 1984; Bülow et al. 1987; Nemoto et al. 1988; Yurina et al. 1988; Baumgartner and Mullet 1991) that could have functionally replaced the bacterial histone-like HU (for histone-like protein from $E$. coli strain U93) proteins which are involved in formation of nucleosome-like structures in bacterial chromosomes (Rouviere-Yaniv and Gross 1975). Among these proteins are several low molecular weight proteins $(10-20 \mathrm{kDa})$ detected by cross-reaction with antibodies directed toward the bacterial HU (Briat et al. 1984). Such basic low molecular weight proteins of eukaryotic origin could have replaced the bacterial histonelike proteins as has been hypothesized earlier (Kodama 2007).

\section{Bifunctionality and dual targeting of ptNAPs}

An intriguing aspect is the association of metabolic/biosynthetic chloroplast functions with nucleoid fractions that have been found, as detailed in the corresponding chapters above. In this context, the repeated discovery of NAPs such as SiR and CND41 with homology to proteins possessing known metabolic functions (see Table 1) seems to corroborate that in nucleoids a tight linkage between gene expression and metabolism exists. While on one hand the level of gene expression determines the metabolic activity, metabolic enzymes on the other hand may directly give feed back to the genetic machinery by influencing, for example, accessibility of transcription factors and core enzymes to promoters. How exactly the bifunctional ptNAPs contribute to the regulation of nucleoid structure and gene expression is in most cases unknown and awaits future investigations. The association of yeast and human mitochondrial nucleoids with metabolic enzymes whose occurrence seems to be highly conserved between different fungal and mammalian species (Nosek et al. 2006) has triggered the hypothesis that such activities could mediate signal transduction from metabolic stimuli to the nucleoids and invoke structural changes (Kucej and Butow 2007). Well documented examples of bifunctional proteins associated with chloroplast nucleoids are $\mathrm{SiR}, \mathrm{FSD} 2 / \mathrm{FSD} 3$ or the CND41 protein (Table 1).
In several nucleoid preparations, subunits of the chloroplast Clp protease system could be identified (Table 1). This fits with the recent notion that ATP-dependent proteases (AAA + proteases) appear to be associated with eubacterial and mitochondrial nucleoids (Ambro et al. 2012). It is postulated that AAA + proteases could control the level of several abundant DNA-binding proteins and in this way regulate many nucleoid-associated processes. Moreover, they could be involved directly in the regulation of gene transcription by controlling the cellular level of transcriptional regulators and thereby could influence the formation of active transcription complexes (Ambro et al. 2012). For two E. coli proteases (Lon and ClpA) a direct binding to DNA could be shown (Zehnbauer et al. 1981; Kubik et al. 2012). In a proteomic study of the Clp protease complexes from Arabidopsis thaliana three Clp AAA+ chaperones $(\mathrm{C} 1, \mathrm{C} 2, \mathrm{D})$ that possess chloroplast targeting sequences and are similar to the $E$. coli $\mathrm{ClpA}$ could be identified (Peltier et al. 2004). The homolog of the Arabidopsis ClpC1 was identified as a component of the TAC fraction isolated from spinach (Melonek et al. 2012) as well as nucleoid-enriched fractions from pea (Phinney and Thelen 2005) and maize (Majeran et al. 2012). In the latter case also the ClpD subunit could be found (Majeran et al. 2012) (Table 1). Further investigations will be needed to unravel a possible role of AAA+ proteases in the regulation of plastid nucleoid dynamics and metabolism.

Several of the plastid DNA binding proteins that were experimentally identified possess motifs that are typically found in nuclear transcription factors (Kodama 2007). Examples are PEND, CND41, PD1, PD3 (Kodama 2007) as well as Whirly1 (Krause et al. 2005; Grabowski et al. 2008) and the newly identified ptNAP SWIB-4 (Melonek et al. 2012). It has been suggested that these proteins have changed their subcellular localization during evolution and became plastid or dually targeted proteins. For some of these proteins experimental evidence for a dual localization in plastids and in the nucleus has already been obtained (Grabowski et al. 2008; Terasawa and Sato 2009; Chen et al. 2010; Isemer et al. 2012) and functions of the plastidic and nuclear isoforms have been analyzed (Table 2). Two in silico studies performed on eukaryotic transcription factors have revealed that a considerable number of these proteins with a nuclear localization sequence also have an N-terminal plastid targeting sequence, increasing the number of putative dually targeted DNA-binding proteins significantly (Wagner and Pfannschmidt 2006; Schwacke et al. 2007). Among the DNA binding proteins predicted to be dually located, some were initially described to have functions in nuclear chromatin remodeling. This occurrence of chromatin remodeling proteins with functions in the nucleus and plastids could imply that communication between plastids and the nucleus occurs by dynamic 
Table 2 Examples for identified or putative ptNAPs from Arabidopsis that are dually targeted to plastids and the nucleus

\begin{tabular}{|c|c|c|c|}
\hline NAP & AGI code & Plastid function & Nuclear function \\
\hline PEND & At3g52170 & $\begin{array}{l}\text { Anchorage to envelope membranes } \\
\text { (Sato et al. 1993; Sato and Ohta 2001) }\end{array}$ & $\begin{array}{l}\text { Unknown (Terasawa and Sato } \\
\text { 2009) }\end{array}$ \\
\hline MFP1 & At3g16000 & $\begin{array}{l}\text { Anchorage to thylakoid membranes } \\
\text { (Jeong et al. 2003) }\end{array}$ & $\begin{array}{l}\text { Chromatin attachment to the } \\
\text { nuclear envelope (Meier et al. } \\
\text { 1996) }\end{array}$ \\
\hline Whirly1 & At1g14410 & $\begin{array}{l}\text { SsDNA and RNA binding; } \\
\text { recombination (Marechal and Brisson } \\
\text { 2010; Melonek et al. 2010; Pfalz et al. } \\
\text { 2006; Prikryl et al. 2008) }\end{array}$ & $\begin{array}{l}\text { Transcription factor and telomere } \\
\text { homeostasis (Desveaux et al. } \\
\text { 2000; Yoo et al. 2007) }\end{array}$ \\
\hline SWIB-4 & At3g03590 & Unknown (Melonek et al. 2012) & $\begin{array}{l}\text { Component of SWI/SNF } \\
\text { chromatin remodeling } \\
\text { complexes (Melonek et al. } \\
\text { 2012) }\end{array}$ \\
\hline $\begin{array}{l}\text { pTAC12/ } \\
\text { HEMERA/ } \\
\text { PAP5 }\end{array}$ & At2g34640 & $\begin{array}{l}\text { Component of the plastid transcriptional } \\
\text { apparatus, subunit of plastid-encoded } \\
\text { RNA-polymerase complex (Gao et al. } \\
\text { 2011; Pfalz et al. 2006; Steiner et al. } \\
\text { 2011) }\end{array}$ & $\begin{array}{l}\text { Phytochrome signaling } \\
\text { (Chen et al. 2010) }\end{array}$ \\
\hline $\operatorname{SIB} 1+2^{\mathrm{a}}$ & $\begin{array}{l}\text { At3g56710 } \\
\text { At2g41180 }\end{array}$ & $\begin{array}{l}\text { Interacting with Sigma factor Sig1 } \\
\text { (Morikawa et al. 2002) }\end{array}$ & $\begin{array}{l}\text { Activation of WRKY33, pathogen } \\
\text { response (Lai et al. 2011) }\end{array}$ \\
\hline
\end{tabular}

AGI Arabidopsis gene identifier

a SIB1 and 2 were not identified by current nucleoid proteomes regarded as sensors of environmental changes (Bouvier et al. 2009) that are perceived as imbalances in electron flow resulting in changes in the redox state of the plastoquinone pool and other redox systems of chloroplasts (Pfannschmidt et al. 2009). These imbalances are known to alter the transcription of a number of plastid genes (Pfannschmidt et al. 1999). Considering the tight association of nucleoids and thylakoids, a direct perception of redox changes in the photosynthetic apparatus by redox sensitive proteins in the nucleoids as also reported for a soluble RNA polymerase preparation from chloroplasts (Schröter et al. 2010) must be expected.

Acknowledgments Research on DNA binding proteins of plastids in the authors' laboratories is supported by DFG Grants $1350 / 1$ and $1350 / 8$ to K. Krupinska and by NFR Grant $185685 /$ V40 to K. Krause.

\section{References}

Ahlert D, Stegemann S, Kahlau S, Ruf S, Bock R (2009) Insensitivity of chloroplast gene expression to DNA methylation. Mol Genet Genom 282:17-24

Ambro L, Pevala V, Bauer J, Kutejova E (2012) The influence of ATP-dependent proteases on a variety of nucleoid-associated processes. J Struct Biol 179:181-192

Arsova B, Hoja U, Wimmelbacher M, Greiner E, Ustun S, Melzer M, Petersen K, Lein W, Bornke F (2010) Plastidial thioredoxin z interacts with two fructokinase-like proteins in a thiol-dependent manner: evidence for an essential role in chloroplast development in Arabidopsis and Nicotiana benthamiana. Plant Cell 22:1498-1515

Azevedo J, Courtois F, Hakimi MA, Demarsy E, Lagrange T, Alcaraz JP, Jaiswal P, Marechal-Drouard L, Lerbs-Mache S (2008) Intraplastidial trafficking of a phage-type RNA polymerase is 
mediated by a thylakoid RING-H2 protein. Proc Natl Acad Sci USA 105:9123-9128

Baumgartner B, Mullet J (1991) Plastid DNA synthesis and nucleic acid-binding proteins in developing barley chloroplasts. J Photochem Photobiol B 11:203-218

Bendich AJ (1987) Why do chloroplasts and mitochondria contain so many copies of their genome. BioEssays 6:279-282

Bendich AJ (2004) Circular chloroplast chromosomes: the grand illusion. Plant Cell 16:1661-1666

Bennett-Lovsey R, Hart SE, Shirai H, Mizuguchi K (2002) The SWIB and the MDM2 domains are homologous and share a common fold. Bioinformatics 18:626-630

Berger M, Farcas A, Geertz M, Zhelyazkova P, Brix K, Travers A, Muskhelishvili G (2010) Coordination of genomic structure and transcription by the main bacterial nucleoid-associated protein HU. EMBO Rep 11:59-64

Bock R (2007) Structure, function, and inheritance of plastid genomes. In: Bock R (ed) Cell and molecular biology of plastids Topics in Current Genetics, vol 19. Springer, Heidelberg, pp 29-62

Boffey S, Ellis R, Selldén G, Leech R (1979) Chloroplast division and DNA synthesis in light-grown wheat leaves. Plant Physiol 64:502-505

Bogenhagen D, Rousseau D, Burke S (2008) The layered structure of human mitochondrial DNA nucleoids. J Biol Chem 283:3665-3675

Bouvier F, Mialoundama AS, Camara B (2009) A sentinel role for plastids. In: Sandelius AS, Aronsson H (eds) The chloroplast. Springer, Berlin, pp 267-292

Briat J, Gigot C, Laulhere J, Mache R (1982) Visualization of a spinach plastid transcriptionally active DNA-protein complex in a highly condensed structure. Plant Physiol 69:1205-1211

Briat J-F, Letoffe S, Mache R, Rouviere-Yaniv J (1984) Similarity between the bacterial histone-like protein $\mathrm{HU}$ and a protein from spinach chloroplasts. FEBS Lett 172:75-79

Bülow S, Reiss T, Link G (1987) DNA-binding proteins of the transcriptionally active chromosome from mustard (Sinapis alba L.) chloroplasts. Curr Genet 12:157-159

Burns L, Peterson CL (1997) Protein complexes for remodeling chromatin. Biochim Biophys Acta 1350:159-168

Cabrera JE, Jin DJ (2003) The distribution of RNA polymerase in Escherichia coli is dynamic and sensitive to environmental cues. Mol Microbiol 50:1493-1505

Cabrera JE, Jin DJ (2006) Active transcription of rRNA operons is a driving force for the distribution of RNA polymerase in bacteria: effect of extrachromosomal copies of $r r n B$ on the in vivo localization of RNA polymerase. J Bacteriol 188:4007-4014

Cannon GC, Ward LN, Heinhorst S (1997) Protein function and composition of plastid nucleoids. Plant Physiol 114:853

Cannon GC, Ward LN, Case CI, Heinhorst S (1998) The 68 kDa DNA compacting nucleoid protein from soybean chloroplasts inhibits DNA synthesis in vitro. Plant Mol Biol 39:835-845

Chan YH, Kwok ACM, Tsang JSH, Wong JTY (2006) Alveolata histone-like proteins have different evolutionary origins. J Evol Biol 19:1717-1721

Chen M, Galvao RM, Li MN, Burger B, Bugea J, Bolado J, Chory J (2010) Arabidopsis HEMERA/pTAC12 initiates photomorphogenesis by phytochromes. Cell 141:1230-1240

Coleman AW, Nerozzi AM (1999) Temporal and spatial coordination of cells with their plastid component. Int Rev Cytol 193:125-164

Desveaux D, Després C, Joyeux A, Subramaniam R, Brisson N (2000) PBF-2 is a novel single-stranded DNA binding factor implicated in the $P R-10 a$ gene activation in potato. Plant Cell 12:1477-1489

Dillon SC, Dorman CJ (2010) Bacterial nucleoid-associated proteins, nucleoid structure and gene expression. Nat Rev Microbiol 8:185-195
Gao ZP, Yu QB, Zhao TT, Ma Q, Chen GX, Yang ZN (2011) A functional component of the transcriptionally active chromosome complex, Arabidopsis pTAC14, interacts with pTAC12/ HEMERA and regulates plastid gene expression. Plant Physiol 157:1733-1745

Gowrishankar J, Harinarayanan R (2004) Why is transcription coupled to translation in bacteria? Mol Microbiol 54:598-603

Grabowski E, Miao Y, Mulisch M, Krupinska K (2008) Singlestranded DNA binding protein Whirly1 in barley leaves is located in chloroplasts and nuclei of the same cell. Plant Physiol 147:1800-1804

Grasser KD (1995) Plant chromosomal high mobility group (HMG) proteins. Plant J 7:185-192

Gruissem W, Tonkyn JC (1993) Control mechanisms of plastid gene expression. Crit Rev Plant Sci 12:19-55

Hallick R, Lipper C, Richards O, Rutter W (1976) Isolation of a transcriptionally active chromosome from chloroplasts of Euglena gracilis. Biochemistry 15:3039-3045

Hansmann P, Falk H, Ronai K, Sitte P (1985) Structure, composition, and distribution of plastid nucleoids in Narcissus pseudonarcissus. Planta 164:459-472

Heinhorst S, Cannon GC (1993) DNA replication in chloroplasts. J Cell Sci 104:1-9

Herrmann RG, Kowallick KV, Bohnert HJ (1974) Structural and functional aspects of the plastome. I. The organization of the plastome. Port Acta Biol Ser A 14:91-110

Igloi G, Kössel H (1992) The transcriptional apparatus of chloroplasts. Crit Rev Plant Sci 10:525-558

Ingelsson B, Vener AV (2012) Phosphoproteomics of Arabidopsis chloroplasts reveals involvement of the STN7 kinase in phosphorylation of nucleoid protein pTAC16. FEBS Lett 586:1265-1271

Isemer R, Mulisch M, Schafer A, Kirchner S, Koop HU, Krupinska K (2012) Recombinant Whirly1 translocates from transplastomic chloroplasts to the nucleus. FEBS Lett 586:85-88

Jaffé B, Kovács K, Andras C, Bódi Z, Liu Z, Fray RG (2008) Methylation of chloroplast DNA does not affect viability and maternal inheritance in tobacco and may provide a strategy toward transgene containment. Plant Cell Rep 27:1377-1384

Jeong SY, Rose A, Meier I (2003) MFP1 is a thylakoid-associated, nucleoid-binding protein with a coiled-coil structure. Nucleic Acids Res 31:5175-5185

Kabeya Y, Nakanishi H, Suzuki K, Ichikawa T, Kondou Y, Matsui M, Miyagishima SY (2010) The YlmG protein has a conserved function related to the distribution of nucleoids in chloroplasts and cyanobacteria. BMC Plant Biol 10:57

Kang YW, Lee JY, Jeon Y, Cheong GW, Kim M, Pai HS (2010) In vivo effects of $\mathrm{NbSiR}$ silencing on chloroplast development in Nicotiana benthamiana. Plant Mol Biol 72:569-583

Karcher D, Koster D, Schadach A, Klevesath A, Bock R (2009) The Chlamydomonas chloroplast HLP protein is required for nucleoid organization and genome maintenance. Mol Plant 2:1223-1232

Kato Y, Murakami S, Yamamoto Y, Chatani H, Kondo Y, Nakano T, Yokota A, Sato F (2004) The DNA-binding protease, CND41, and the degradation of ribulose-1,5-bisphosphate carboxylase/oxygenase in senescent leaves of tobacco. Planta 220:97-104

Kobayashi H, Ngernprasirtsiri J, Akazawa T (1990) Transcriptional regulation and DNA methylation in plastids during transitional conversion of chloroplasts to chromoplasts. EMBO J 9:307-313

Kodama Y (2007) Plastidic proteins containing motifs of nuclear transcription factors. Plant Biotechnol 24:165-170

Krause K, Krupinska K (2000) Molecular and functional properties of highly purified transcriptionally active chromosomes from spinach chloroplasts. Physiol Plant 109:188-195 
Krause K, Krupinska K (2009) Nuclear regulators with a second home in organelles. Trends Plant Sci 14:194-199

Krause K, Kilbienski I, Mulisch M, Rodiger A, Schafer A, Krupinska $\mathrm{K}$ (2005) DNA-binding proteins of the Whirly family in Arabidopsis thaliana are targeted to the organelles. FEBS Lett 579:3707-3712

Krupinska K (1992) Transcriptional control of plastid gene expression during development of primary foliage leaves of barley grown under a daily light-dark regime. Planta 186:294-303

Kubik S, Wegrzyn K, Pierechod M, Konieczny I (2012) Opposing effects of DNA on proteolysis of a replication initiator. Nucleic Acids Res 40:1148-1159

Kucej M, Butow RA (2007) Evolutionary tinkering with mitochondrial nucleoids. Trends Cell Biol 17:586-592

Kuroiwa T (1991) The replication, differentiation, and inheritance of plastids with emphasis on the concept of organelle nuclei. Int Rev Cytol 128:1-62

Kuroiwa T, Kawano S, Nishibayashi S, Sato C (1982) Epifluorescent microscopic evidence for maternal inheritance of chloroplast DNA. Nature 298:481-483

Kuroiwa T, Kuroiwa H, Mita T, Fujie M (1990) Fluorescence microscopic study of the formation of giant mitochondrial nuclei in the young ovules of Pelargonium zonale. Protoplasma 158:191-194

Lai Z, Li Y, Wang F, Cheng Y, Fan B, Yu JQ, Chen Z (2011) Arabidopsis sigma factor binding proteins are activators of the WRKY33 transcription factor in plant defense. Plant Cell 23:3824-3841

Liere K, Weihe A, Borner T (2011) The transcription machineries of plant mitochondria and chloroplasts: composition, function, and regulation. J Plant Physiol 168:1345-1360

Majeran W, Friso G, Asakura Y, Qu X, Huang M, Ponnala L, Watkins KP, Barkan A, van Wijk KJ (2012) Nucleoid-enriched proteomes in developing plastids and chloroplasts from maize leaves; a new conceptual framework for nucleoid function. Plant Physiol 158:156-189

Marechal A, Brisson N (2010) Recombination and the maintenance of plant organelle genome stability. New Phytol 186:299-317

Marechal A, Parent JS, Veronneau-Lafortune F, Joyeux A, Lang BF, Brisson N (2009) Whirly proteins maintain plastid genome stability in Arabidopsis. Proc Natl Acad Sci USA 106:1469314698

Matera AG, Izaguire-Sierra M, Praveen K, Rajendra TK (2009) Nuclear bodies: random aggregates of sticky proteins or crucibles of macromolecular assembly? Dev Cell 17:639-647

Meeusen S, Nunnari J (2003) Evidence for a two membrane-spanning autonomous mitochondrial DNA replisome. J Cell Biol 163:503-510

Meier I, Phelan T, Gruissem W, Spiker S, Schneider D (1996) MFP1, a novel plant filament-like protein with affinity for matrix attachment region DNA. Plant Cell 8:2105-2115

Melonek J, Mulisch M, Schmitz-Linneweber C, Grabowski E, Hensel G, Krupinska K (2010) Whirly1 in chloroplasts associates with intron containing RNAs and rarely co-localizes with nucleoids. Planta 232:471-481

Melonek J, Matros A, Trosch M, Mock HP, Krupinska K (2012) The core of chloroplast nucleoids contains architectural SWIB domain proteins. Plant Cell 24:3060-3073

Morikawa K, Shiina T, Murakami S, Toyoshima Y (2002) Novel nuclear-encoded proteins interacting with a plastid sigma factor, Sig1, in Arabidopsis thaliana. FEBS Lett 514:300-304

Moriyama T, Terasawa K, Sekine K, Toyoshima M, Koike M, Fujiwara M, Sato N (2010) Characterization of cell-cycle-driven and light-driven gene expression in a synchronous culture system in the unicellular rhodophyte Cyanidioschyzon merolae. Microbiology 156:1730-1737
Mullet JE (1993) Dynamic regulation of chloroplast transcription. Plant Physiol 103:309-313

Murakami S, Kondo Y, Nakano T, Sato F (2000) Protease activity of CND41, a chloroplast nucleoid DNA-binding protein, isolated from cultured tobacco cells. FEBS Lett 468:15-18

Myouga F, Hosoda C, Umezawa T, Iizumi H, Kuromori T, Motohashi R, Shono Y, Nagata N, Ikeuchi M, Shinozaki K (2008) A heterocomplex of iron superoxide dismutases defends chloroplast nucleoids against oxidative stress and is essential for chloroplast development in Arabidopsis. Plant Cell 20:3148-3162

Nakano T, Sato F, Yamada Y (1993) Analysis of nucleoid-proteins in tobacco chloroplasts. Plant Cell Physiol 34:873-880

Nakano T, Murakami S, Shoji T, Yoshida S, Yamada Y, Sato F (1997) A novel protein with DNA binding activities from tobacco chloroplast nucleoids. Plant Cell 9:1673-1682

Nemoto Y, Kawano S, Nakamura S, Mita T, Nagata T, Kuroiwa T (1988) Studies on plastid-nuclei (nucleoids) in Nicotiana tabacum L.I. Isolation of proplastid-nuclei from cultured cells and identification of proplastid-nuclear proteins. Plant Cell Physiol 29:167-177

Ngernprasirtsiri J, Kobayashi H, Akazawa T (1988a) DNA methylation as a mechanism of transcriptional regulation in nonphotosynthetic plastids in plant cells. Proc Natl Acad Sci USA $85: 4750-4754$

Ngernprasirtsiri J, Kobayashi H, Akazawa T (1988b) DNA methylation occurred around lowly expressed genes of plastid DNA during tomato fruit development. Plant Physiol 88:16-20

Ngernprasirtsiri J, Kobayashi H, Akazawa T (1990) DNA methylation is a determinative element of photosynthesis gene expression in amyloplasts from liquid-cultured cells of sycamore (Acer pseudoplatanus L.). Cell Struct Funct 15:285-293

Nosek J, Tomaska L, Bolotin-Fukuhara M, Miyakawa I (2006) Mitochondrial chromosome structure: an insight from analysis of complete yeast genomes. FEMS Yeast Res 6:356-370

Ono Y, Sakai A, Takechi K, Takio S, Takusagawa M, Takano H (2007) NtPoll-like1 and NtPoll-like2, bacterial DNA polymerase I homologs isolated from BY-2 cultured tobacco cells, encode DNA polymerases engaged in DNA replication in both plastids and mitochondria. Plant Cell Physiol 48:1679-1692

Parrott D, McInnerney K, Feller U, Fischer A (2007) Steam-girdling of barley (Hordeum vulgare) leaves leads to carbohydrate accumulation and accelerated leaf senescence, facilitating transcriptomic analysis of senescence-associated genes. New Phytol 176:56-69

Peltier JB, Ripoll DR, Friso G, Rudella A, Cai Y, Ytterberg J, Giacomelli L, Pillardy J, van Wijk KJ (2004) Clp protease complexes from photosynthetic and non-photosynthetic plastids and mitochondria of plants, their predicted three-dimensional structures, and functional implications. J Biol Chem 279:4768-4781

Pfalz J, Liere K, Kandlbinder A, Dietz K-J, Oelmüller R (2006) pTAC2, -6 , and -12 are components of the transcriptionally active plastid chromosome that are required for plastid gene expression. Plant Cell 18:176-197

Pfannschmidt T, Link G (1994) Separation of two classes of plastid DNA-dependent RNA polymerases that are differentially expressed in mustard (Sinapis alba L.) seedlings. Plant Mol Biol 25:69-81

Pfannschmidt T, Nilsson A, Allen JF (1999) Photosynthetic control of chloroplast gene expression. Nature 397:625-628

Pfannschmidt T, Bräutigam K, Wagner R, Dietzel L, Schröter Y, Steiner S, Nykytenko A (2009) Potential regulation of gene expression in photosynthetic cells by redox and energy state: approaches toward better understanding. Ann Bot 103:599-607 
Phinney BS, Thelen JJ (2005) Proteomic characterization of a Tritoninsoluble fraction from chloroplasts defines a novel group of proteins associated with macromolecular structures. J Proteome Res 4:497-506

Prikryl J, Watkins KP, Friso G, van Wijk KJ, Barkan A (2008) A member of the Whirly family is a multifunctional RNA- and DNA-binding protein that is essential for chloroplast biogenesis. Nucleic Acids Res 36:5152-5165

Rouviere-Yaniv J, Gross F (1975) Characterization of a novel, lowmolecular-weight DNA-binding protein from Escherichia coli. Proc Natl Acad Sci USA 72:3428-3432

Ruwe H, Kupsch C, Teubner M, Schmitz-Linneweber C (2011) The RNA-recognition motif in chloroplasts. J Plant Physiol 168:1361-1371

Sakai A, Takano H, Kuroiwa H (2004) Organelle nuclei in higher plants: structure, composition, function, and evolution. Int Rev Cytol 238:59-118

Sakamoto W, Uno Y, Zhang Q, Miura E, Kato Y, Sodmergen (2009) Arrested differentiation of proplastids into chloroplasts in variegated leaves characterized by plastid ultrastructure and nucleoid morphology. Plant Cell Physiol 50:2069-2083

Saotome A, Kimura S, Mori Y, Uchiyama Y, Morohashi K, Sakaguchi K (2006) Characterization of four RecQ homologues from rice (Oryza sativa L. cv. Nipponbare). Biochem Biophys Res Commun 345:1283-1291

Sato N, Ohta N (2001) DNA-binding specificity and dimerization of the DNA-binding domain of the PEND protein in the chloroplast envelope membrane. Nucleic Acids Res 29:2244-2250

Sato N, Albrieux C, Joyard J, Douce R, Kuroiwa T (1993) Detection and characterization of a plastid envelope DNA-binding protein which may anchor plastid nucleoids. EMBO J 12:555-561

Sato N, Misumi O, Joyard J, Douce R (1995) DNA-binding proteins mediate interaction of nucleoids with envelope membranes in developing plastids. In: Mathis P (ed) Photosynthesis: from light to biospere. Kluwer Academic Publishers, Dordrecht, pp 635-638

Sato N, Ohshima K, Watanabe A, Ohta N, Nishiyama Y, Joyard J, Douce R (1998) Molecular characterization of the PEND protein, a novel bZIP protein present in the envelope membrane that is the site of nucleoid replication in developing plastids. Plant Cell 10:859-872

Sato N, Nakayama M, Hase T (2001) The 70-kDa major DNAcompacting protein of the chloroplast nucleoid is sulfite reductase. FEBS Lett 487:347-350

Sato N, Terasawa K, Miyajima K, Kabeya Y (2003) Organization, developmental dynamics, and evolution of plastid nucleoids. Int Rev Cytol 232:217-262

Schmitz-Linneweber C, Small I (2008) Pentatricopeptide repeat proteins: a socket set for organelle gene expression. Trends Plant Sci 13:663-670

Schröter Y, Steiner S, Matthäi K, Pfannschmidt T (2010) Analysis of oligomeric protein complexes in the chloroplast sub-proteome of nucleic acid-binding proteins from mustar reveals potential redox regulators of plastid gene expression. Proteomics 10:2191-2204

Schwacke R, Fischer K, Ketelsen B, Krupinska K, Krause K (2007) Comparative survey of plastid and mitochondrial targeting properties of transcription factors in Arabidopsis and rice. Mol Genet Genomics 277:631-646

Sekine K, Hase T, Sato N (2002) Reversible DNA compaction by sulfite reductase regulates transcriptional activity of chloroplast nucleoids. J Biol Chem 277:24399-24404

Sekine K, Fujiwara M, Nakayama M, Takao T, Hase T, Sato N (2007) DNA binding and partial nucleoid localization of the chloroplast stromal enzyme ferredoxin: sulfite reductase. FEBS J 274:2054-2069

Shaw PJ, Brown JW (2004) Plant nuclear bodies. Curr Opin Plant Biol 7:614-620

Shutt TE, Lodeiro MF, Cotney J, Cameron CE, Shadel GS (2010) Core human mitochondrial transcription apparatus is a regulated two-component system in vitro. Proc Natl Acad Sci USA 107:12133-12138

Steiner S, Schröter Y, Pfalz J, Pfannschmidt T (2011) Identification of essential subunits in the plastid-encoded RNA polymerase complex reveals building blocks for proper plastid development. Plant Physiol 157:1043-1055

Suzuki JY, Ytterberg AJ, Beardslee TA, Allison LR, Van Wijk KJ, Maliga P (2004) Affinity purification of the tobacco plastid RNA polymerase and in vitro reconstitution of the holoenzyme. Plant $\mathrm{J}$ 40:164-172

Terasawa K, Sato N (2005a) Occurrence and characterization of PEND proteins in angiosperms. J Plant Res 118:111-119

Terasawa K, Sato N (2005b) Visualization of plastid nucleoids in situ using the PEND-GFP fusion protein. Plant Cell Physiol 46:649-660

Terasawa K, Sato N (2009) Plastid localization of the PEND protein is mediated by a noncanonical transit peptide. FEBS J 276:1709-1719

Travers A, Muskhelishvili G (2005) Bacterial chromatin. Curr Opin Genet Dev 5:507-514

Wagner R, Pfannschmidt T (2006) Eukaryotic transcription factors in plastids-Bioinformatic assessment and implications for the evolution of gene expression machineries in plants. Gene 381:62-70

Waldmüller S, Müller U, Link G (1996) GSBF1, a seedling-specific bZIP DNA-binding protein with preference for a 'split' G-boxrelated element in Brassica napus RbcS promoters. Plant Mol Biol 32:631-639

Weber P, Fulgosi H, Piven I, Muller L, Krupinska K, Duong VH, Herrmann RG, Sokolenko A (2006) TCP34, a nuclear-encoded response regulator-like TPR protein of higher plant chloroplasts. J Mol Biol 357:535-549

Wycliffe P, Sitbon F, Wernerson J, Ezcurra I, Ellerström M, Rask L (2005) Continuous expression in tobacco leaves of a Brassica napus PEND homologue blocks differentiation of plastids and development of palisade cells. Plant J 44:1-15

$\mathrm{Xu}$ YZ, Arrieta-Montiel MP, Virdi KS, de Paula WB, Widhalm JR, Basset GJ, Davila JI, Elthon TE, Elowsky CG, Sato SJ, Clemente TE, Mackenzie SA (2011) MutS HOMOLOG1 is a nucleoid protein that alters mitochondrial and plastid properties and plant response to high light. Plant Cell 23:3428-3441

Yagi Y, Ishizaki Y, Nakahira Y, Tozawa Y, Shiina T (2012) Eukaryotic-type plastid nucleoid protein pTAC3 is essential for transcription by the bacterial-type plastid RNA polymerase. Proc Natl Acad Sci USA 109:7541-7546

Yoo HH, Kwon C, Lee MM, Chung IK (2007) Single-stranded DNA binding factor AtWHY1 modulates telomere length homeostasis in Arabidopsis. Plant J 49:442-451

Yoshida Y, Laulhere JP, Rozier C, Mache R (1975) Visualization of folded chloroplast DNA from spinach. Biol Cell 32:187-190

Yurina NP, Belkina GG, Pozhidaeva EV, Turishcheva MS, Odintsova MS (1988) DNA-protein complex from pea chloroplastsIsolation and characterization. Mol Biol 22:99-105

Zehnbauer BA, Foley EC, Henderson GW, Markovitz A (1981) Identification and purification of the Lon+ (Capr+) gene product, a DNA-binding protein. Proc Natl Acad Sci USA 78:2043-2047 